\title{
APLIKASI TEKNOLOGI INDUCED SPAWNING UNTUK MEMPERCEPAT PEMIJAHAN IKAN LELE PADA MITRA PROGRAM KEMITRAAN MASYARAKAT
}

\section{Application of Induced Spawning Technology to Accelerate Catfish Spawning in Community Partnership Program Partners}

\author{
Akhmad Taufiq Mukti ${ }^{1 *}$, Ahmad Shofy Mubarak ${ }^{2}$, dan Endang Tri Wahyurini ${ }^{3}$ \\ ${ }^{1}$ Departemen Manajemen Kesehatan Ikan dan Budidaya Perairan, Fakultas Perikanan dan Kelautan, Universitas \\ Airlangga, Surabaya 60115 \\ ${ }^{2}$ Departemen Kelautan, Fakultas Perikanan dan Kelautan, Universitas Airlangga, Surabaya 60115. \\ ${ }^{3}$ Fakultas Pertanian, Universitas Islam Madura, Pamekasan, Madura \\ *akhmad-t-m@fpk.unair.ac.id
}

Tujuan penelitian ini adalah mengetahui pengaruh TIS terhadap pecepatan pemijahan ikan lele di Desa Pakamban Laok, Kecamatan Pragaan, Kabupaten Sumenep, Madura sekaligus memperkenalkan teknologi tersebut melalui program kemitraan masyarakat. Metode kegiatan adalah penyuluhan dan diskusi, pelatihan, praktek dan demoplot pengaruh TIS terhadap daya tetas telur ikan lele serta pendampingan berkelanjutan. TIS dapat mempercepat proses kematangan gonad dan pemijahan induk ikan lele dengan fekunditas dan penetasan lebih tinggi daripada pemijahan alami. TIS dapat meningkatkan jumlah telur fertilisasi $100 \%$ dan hatching rate $95 \%$.

Kata kunci: Teknologi Induced Spawning, Pemijahan, Ikan Lele, Madura

\begin{abstract}
The purpose of this study was to determine the effect of TIS to accelerate catfish spawning in Pakamban Laok Village, Pragaan Subdistrict, Sumenep Regency, Madura while introducing the technology through community partnership programs. The method of activity was counseling and discussion, training, practice and demonstration of the influence of TIS on the hatchability of catfish eggs and ongoing assistance. TIS could accelerate the process of gonadal maturation and spawning of catfish with higher fecundity and hatching than natural spawning.
\end{abstract}

Keywords : Induced Spawning Technology, Spawning, Catfish, Madura

\section{PENDAHULUAN}

Pengembangan usaha agribisnis budidaya ikan lele merupakan pilihan yang tepat bagi masyarakat pedesaan atau pesisir hingga saat ini, selain ikan nila. Ikan lele merupakan salah satu komoditas perikanan air tawar yang memiliki prospek tinggi untuk perdagangan maupun pemenuhan konsumsi keluarga. Hal ini dikarenakan ikan lele mudah dikembangbiakkan dan dibudidayakan, meskipun dalam kondisi lahan terbatas. Permintaan konsumsi ikan lele yang cukup tinggi saat ini membuat produksi ikan lele dumbo sangat potensial untuk ditingkatkan.

Permasalahan utama yang dihadapi oleh pembudidaya ikan lele dalam pengem- bangan agribisnis perikanan, khususnya budidaya ikan lele adalah ketersediaan benih untuk budidaya yang sangat terbatas. Selain itu, pengadaan benih ikan lele dari luar daerah menjadi kendala besar, terutama modal yang dikeluarkan sangat tinggi, sehingga seringkali tidak seimbang dengan hasil produksi yang didapatkan.

Budidaya ikan terutama pembenihan merupakan salah satu aspek yang berpotensi dan mulai digemari oleh masyarakat luas. Selain tidak terlalu rumit, biaya yang dibutuhkan juga tidak terlalu tinggi dan dapat dipergunakan sebagai pekerjaan tetap yang mampu meningkatkan pendapatan keluarga. Faktor produksi yang sangat menentukan dalam usaha budidaya 
ikan adalah ketersediaan benih.

Ketersediaan benih merupakan salah satu ukuran keberhasilan usaha budidaya (Mukti, 2002; Mukti dan Rustidja, 2002). Penyediaan benih tidak terlepas dari ketersediaan stok induk. Teknologi Induced Spawning (TIS) terbukti dapat mempercepat proses peningkatan kematangan gonad dan pemijahan beberapa spesies ikan.

Teknologi ini telah banyak diteliti dan diterapkan pada beberapa komoditas perikanan, baik air tawar, payau maupun air laut. TIS pada ikan relatif mudah untuk dilaksanakan oleh masyarakat, karena cukup sederhana dan peralatan yang diperlukan tidak terlalu rumit atau sangat mudah didapat dan terjangkau.

Aplikasi TIS ini telah banyak dikembangkan menggunakan hormon perangsang yang telah resmi diperjualbelikan untuk penggunaan pemijahan semi buatan pada ikan. Peningkatan efektifitas dan efisiensi pemijahan buatan telah dilakukan menggunakan berbagai hormon atau zat perangsang yang diberikan pada induk ikan, sehingga dapat mempercepat pematangan gonad (Mittlemark dan Kapuscinki, 2000). Salah satu metode yang digunakan adalah metode yang didasarkan pada rangsangan pelepasan gonadotropin $(\mathrm{GTH})$ oleh superaktif salmon gonadotropin releasing hormone analoque (sGnRHa) dikombinasi dengan anti dopamin, reseptor antagonis yang mempunyai potensi merespon peptida (Drori et al., 1994), pregnant male serum gonadotropin (PMSG) (Wahyudi, 1995), luteinizing hormon releasing hormon (LHRH) dan human chorionic hormone (hCG) (de Graaf dan Janssen, 1996; Pao et al., 1999).

Syndel Laboratories Inc. Canada telah membuat larutan yang disebut ovaprim. Dibandingkan hormon lain, ovaprim memiliki kelebihan, yaitu sekaligus mengandung analog salmon gonadotropin releasing hormon (sGnRHa) dan anti dopamin (Nandeeska et al., 1990). Ovaprim mengandung superaktif salmon gonadotropin releasing hormone analoque (sGnRHa) dan domperin (anti dopamin) yang dapat merangsang ovulasi ikan betina melalui injeksi.

Hormon ini merangsang organ seks ikan sambil menghambat akifitas dopamin, yaitu substansi yang dihasilkan ikan untuk menghambat ovulasi (IDRC, 1998). Oleh karena itu, tujuan kegiatan ini adalah mengenalkan aplikasi TIS untuk mempercepat pemijahan ikan lele di masyarakat.

\section{METODOLOGI \\ Waktu dan Tempat}

Kegiatan ini dilaksanakan pada bulan Mei-Oktober 2018. Kegiatan ini dilaksanakan di kelompok mitra PKM "Kampong Lele" di Desa Pakamban Laok, Kecamatan Pragaan, Kabupaten Sumenep, Madura.

\section{Materi Penelitian}

Penelitian ini menggunakan indukan ikan lele mutiara 600-800 gram per ekor ikan jantan maupun betina. Dosis ovaprim yang digunakan adalah $0,1 \mathrm{ml}$ per ekor ikan.

\section{Rancangan Penelitian}

Metode pendekatan dalam pelaksanaan kegiatan ini adalah melalui transfer wawasan, iptek yang mudah untuk diaplikasikan serta dikembangkan oleh kelompok mitra yaitu TIS. Sarana tempat penyuluhan dan pelatihan serta praktek (demoplot) secara langsung untuk kegiatan ini telah tersedia di kelompok mitra, bahkan dapat juga nantinya bekerjasama dengan Dinas Kelautan dan Perikanan Kabupaten Sumenep, Madura untuk memfasilitasi kegiatan penyuluhan, pelatihan dan praktek serta pendampingan kelompokmitra.

Pelaksanaan kegiatan ini, meliputi: 1) Penyuluhan melalui penyampaian materi dan diskusi tentang: a) berbagai jenis ikan lele dan penyediaan induk ikan lele berkualitas, b) pematangan induk ikan lele, c) proses pembenihan ikan lele, d) pakan alami yang baik untuk larva atau benih ikan lele, e) cara budidaya ikan lele yang baik, serta f) manajemen usaha dan pengembangan pembenihan dan budidaya ikan lele, ter- 
masuk pasar dan pemasaran ikan lele, 2) Pelatihan dan peningkatan keterampilan aplikasi iptek pematangan dan pemijahan induk ikan lele melalui TIS dan pembenihan serta budidaya ikan lele yang baik, 3) Praktek dan demoplot serta bimbingan teknis aplikasi iptek dan manajemen usaha pembenihan dan budidaya ikan lele, dan 4) Monitoring dan evaluasi kegiatan serta pendampingan pada kelompok mitra secara berkala.

Partisipasi kelompok mitra ini adalah menyediakan sarana dan prasarana selama kegiatan dilaksanakan, seperti tempat pertemuan untuk penyuluhan dan pelatihan serta kolam atau wadah pembenihan dan atau budidaya ikan lele untuk demoplot.

\section{Prosedur Kerja}

Praktek TIS dilakukan oleh dengan menggunakan induk ikan lele mutiara yang berukuran 600-800 gram per ekor ikan jantan maupun betina. Dosis ovaprim yang digunakan adalah $0,1 \mathrm{ml}$ per ekor ikan. Penelitian yang dilakukan adalah induksi ovaprim pada jantan, betina, dan keduanya, kemudian saling dipasangkan.

Praktek TIS dilakukan pada kolam beton dengan ukuran $2 \times 3 \times 1 \mathrm{~m}^{3}$. Substrat yang digunakan sebagai tempat pelekatan telur ikan lele terbuat dari ijuk yang umumnya disebut "kakaban". Perlakuan yang dilakukan adalah:

I : Induk ikan lele jantan (injeksi ovaprim)

$\times$ Induk ikan lele betina (injeksi ovaprim)

II : Induk ikan lele jantan (injeksi ovaprim)

$\times$ Induk ikan lele betina (tanpa ovaprim)

III : Induk ikan lele jantan (tanpa ovaprim)

$\times$ Induk ikan lele betina (injeksi ovaprim)

IV : Induk ikan lele jantan (tanpa ovaprim)

$\times$ Induk ikan lele betina (tanpa ovaprim)

Injeksi ovaprim dilakukan sekali pada pukul 21.00 WIB. Pengamatan keberhasilan pemijahan induk ikan lele dilakukan pada pagi hari sekitar pukul 06.00 WIB dengan mengamati substrat yang digunakan dalam proses pemijahan ikan. Kondisi telur yang melekat pada substrat diamati dan ditentukan persentasenya secara acak dari masing-masing perlakuan uji coba.

\section{Monitoring dan Evaluasi}

Monitoring dan evaluasi kegiatan serta pendampingan pada kelompok mitra dilakukan secara berkala, berkelanjutan dan berkesinambungan yang melibatkan dan berkoordinasi dengan Penyuluh Pendamping Kecamatan serta bekerjasama dengan Dinas terkait (Dinas Kelautan dan Perikanan) Kabupaten Sumenep maupun Dinas Perikanan dan Kelautan Propinsi Jawa Timur.

\section{HASIL DAN PEMBAHASAN}

Hasil kegiatan ini adalah kelompok mitra sangat antusias untuk berperan aktif dalam berpartisipasi. Pada saat diskusi dan meninjau langsung ke lokasi budidaya ikan lele milik ketua kelompok Bapak Ibnu Rusdi menunjukkan bahwa masyarakat sangat layak dan sangat ingin dijadikan mitra kegiatan. Hal ini dapat dilihat pada Gambar 1.

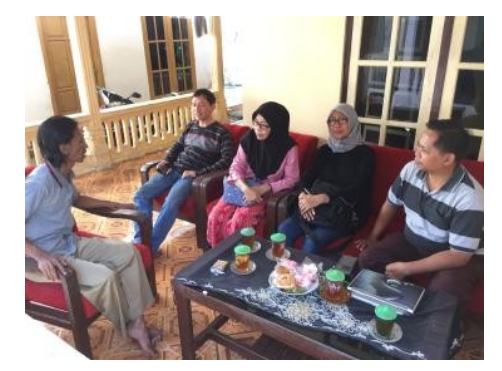

Gambar 1. Diskusi dan peninjauan langsung ke lapang fasilitas budidaya kelompok mitra

Berdasarkan hasil diskusi dan kunjungan langsung ke kelompok mitra kegiatan, maka diperlukan fasilitas (sarana) tambahan untuk pemeliharaan dan pemijahan induk ikan lele. Hal ini bertujuan untuk melancarkan pelaksanaan kegiatan dan keberlanjutan di masa mendatang. Oleh karena itu, perlu dicari tempat atau lahan yang cukup tersedia milik kelompok mitra untuk bantuan pembuatan bak tembok atau sarana pemeliharaan dan pemijahan induk ikan lele, sebagaimana terlihat pada Gambar 2. Bantuan induk ikan lele bersertifikat 
juga dilakukan untuk memperlancar pelaksanaan kegiatan, sebagaimana Gambar 3.

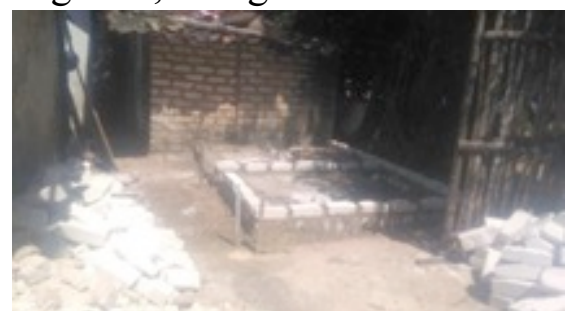

Gambar 2. Penentuan lokasi atau lahan untuk pembuatan bak tembok atau sarana pemeliharaan dan pemijahan induk ikan lele di kelompok mitra
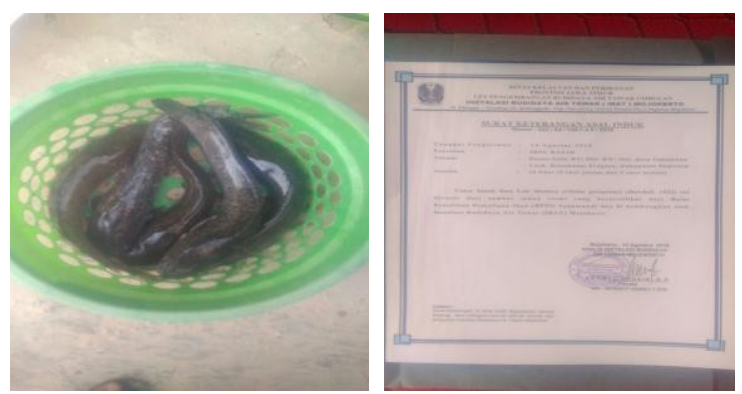

Gambar 3. Induk ikan lele bersertifikat bantuan kegiatan

Hasil kegiatan pelatihan TIS pada anggota kelompok mitra menunjukkan perkembangan pengetahuan dan keterampilan anggota kelompok mitra semakin baik. Hal ini terlihat pada saat diskusi dan pelatihan yang dipraktekkan secara langsung oleh anggota kelompok mitra (Gambar 4).

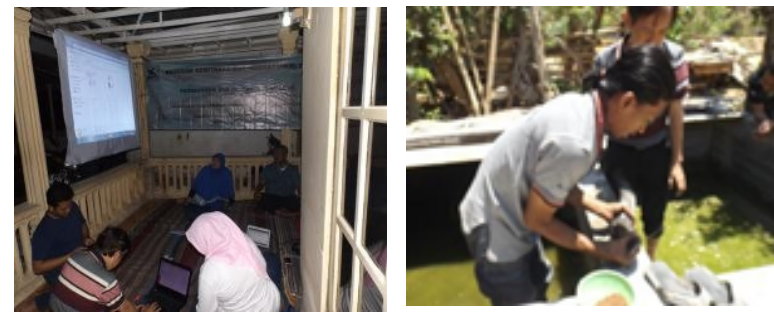

Gambar 4. Kegiatan penyampaian materi dan praktek langsung TIS

Berdasarkan hasil penelitian dan uji coba demplot menggunakan TIS di kelompok mitra menunjukkan hasil yang signifikan. Induk ikan lele jantan dan betina yang diinduksi hormonal menggunakan TIS menghasilkan telur berkualitas yang lebih banyak dibandingkan dengan induk ikan lele betina saja yang diinduksi hormonal.

Selain itu, telur yang berasal dari induk ikan lele betina yang dipasangkan dengan induk ikan lele jantan yang tidak diinduksi hormonal terlihat banyak yang rusak atau tidak terbuahi, sedangkan induk ikan lele, baik jantan maupun betina yang tidak diinduksi hormonal tidak terjadi perkawinan dan tidak menghasilkan pemijahan induk ikan lele betina, sehingga tidak terlihat adanya telur di substrat. Hasil penetasan telur yang berasal dari induk ikan lele yang menggunakan TIS (jantan dan betina) lebih banyak dibandingkan dengan induk ikan lele yang menggunakan TIS anya salah satu induk saja. Hasil penelitian dapat dilihat pada Tabel 1.

Tabel 1. Perbandingan proses dan kualitas pemijahan induk ikan lele mutiara di Desa Pakamban Laok, Kecamatan Pragaan, Kabupaten Sumenep, Madura

\begin{tabular}{cccccc}
\hline $\begin{array}{c}\text { Uji } \\
\text { Coba }\end{array}$ & $\begin{array}{c}\text { Proses } \\
\text { Pemijahan }\end{array}$ & $\begin{array}{c}\text { Jumlah Telur } \\
\text { di Substrat } \\
(\%)\end{array}$ & $\begin{array}{c}\text { Jumlah Telur } \\
\text { Terfertilisasi } \\
(\%)\end{array}$ & $\begin{array}{c}\text { Jumlah Telur } \\
\text { Rusak } \\
(\%)\end{array}$ & $\begin{array}{c}\text { Jumlah Telur } \\
\text { Menetas } \\
(\%)\end{array}$ \\
\hline I & Terjadi & 100 & 100 & 0 & 95 \\
II & Terjadi & 80 & 90 & 10 & 80 \\
III & Terjadi & 100 & 70 & 30 & 80 \\
IV & Tidak Terjadi & - & - & - & - \\
\hline
\end{tabular}

Keterangan:

I : Induk ikan lele jantan dan betina sama-sama diinjeksi ovaprim

II : Induk ikan lele jantan yang diinjeksi ovaprim

III : Induk ikan lele betina yang diinjeksi ovaprim

IV : Induk ikan lele jantan dan betina sama-sama tidak diinjeksi ovaprim 
Aplikasi iptek melalui TIS bermanfaat dalam upaya mempercepat sinkronisasi proses pematangan dan pemijahan induk ikan lele (Clarias gariepinus), sebagaimana hasil penelitian Abdulraheem et al. (2012), Achionye-Nzeh dan Obaroh (2012), Odedeyi et al. (2014), Marimuthu et al. (2015), dan Akombo et al. (2018).

Ovaprim telah banyak diteliti dan bermanfaat dalam mempercepat proses reproduksi dan pemijahan ikan serta meningkatkan kualitas pemijahan beberapa spesies ikan budidaya, seperti ikan patin (Pangasius spp.) (Hassan et al., 2011), seurukan (Osteochilus vittatus) (Muchlisin et al., 2014), karper (Shoaib et al., 2014; Usma et al., 2015), gabus (Channa spp.) (Hafeez-urRehman et al., 2015), Anabas testudineus (Singh et al., 2015), dan catfish (Chaube et al., 2014; Khan et al., 2014; Acharjee et al., 2017; Aryani et al., 2018).

Ovaprim dimanfaatkan sebagai bahan hormon sintetis komersial yang telah lazim dan luas digunakan dalam kegiatan pemijahan ikan di lapangan, terutama spesies ikan endemik atau liar yang baru didomestikasi untuk dikembangbiakkan. Peranan ovaprim dalam menginduksi pemijahan ikan liar hasil tangkapan tampak pada hasil penelitian terhadap ikan benni (Barbus sharpeyi) (Kahkesh et al., 2010), lele lokal (Clarias batrachus) (Charan et al., 2016), Longspine scraper (Capoeta trutta Heckel, 1843) (Zadmajid, 2016; Zadmajid et al., 2017), Levantine scraper (Capoeta damascina Valenciennes, 1842) (Zadmajid et al., 2018), dan nothern pike (Esox lucius) (Cejko et al., 2018). Ovaprim juga telah banyak diaplikasikan untuk mempercepat pemijahan ikan hias komersial yang relatif sulit untuk memijah secara alami.

Aplikasi TIS telah dikembangkan pada beberapa kegiatan pengabdian kepada masyarakat sebelumnya, yaitu Iptek pada daerah rawan pangan dan kemiskinan (Satyantini et al., 2009) dan Iptek bagi Masyarakat (IbM) untuk pengembangan agribisnis perikanan pada Pondok Pesantren (Mukti et al., 2010). TIS merupakan teknologi aplikatif yang dapat dikembang- kan dan disosialisasikan kepada masyarakat luas, terutama bagi masyarakat pembenih ikan.

\section{KESIMPULAN DAN SARAN Kesimpulan}

Kelompok mitra memiliki semangat dan motivasi tinggi untuk mengikuti kegiatan ini dan memiliki pengetahuan dan keterampilan yang cukup baik dalam mengaplikasikan TIS yang diberikan pada kegiatan ini. TIS dapat meningkatkan jumlah telur fertilisasi 100\% dan hatching rate 95\%.

\section{Saran}

Saran yang dapat diberikan adalah perlu adanya kontinyuitas dalam mendampingi mitra masyarakat untuk terus mengembangkan TIS.

\section{UCAPAN TERIMA KASIH}

Ucapan terima kasih kami sampaikan kepada DRPM, Kemenristekdikti atas pendanaan kegiatan PKM tahun anggaran 2018. Terima kasih juga kami sampaikan kepada Rektor melalui Ketua Lembaga Pengabdian kepada Masyarakat Universitas Airlangga atas dukungan yang diberikan dalam pelaksanaan kegiatan PKM ini.

\section{DAFTAR PUSTAKA}

Abdulraheem, I., Otubusin, S.O., Agbebi, O.T., Olowofeso, O., Adeyemi, K.A. and Ashley-Dejo, S.S., 2012. Induced breeding of african catfish (Clarias gariepinus) under varying brood stock ratios. Glob. J. Sci. Front. Res. Agric. Vet. Sci., 12(8), p.52-57.

Acharjee, A., Chaube, R. and Joy, K.P., 2017. Ovaprim, a commercial spawning inducer, stimulates gonadotropin subunit gene transcriptional activity: A study correlated with plasma steroid profile, ovulation and fertilization in the catfish Heteropneustes fossilis. Gen. Comp. Endocrinol., 251, p.6673.

Achionye-Nzeh, C.G. and Obaroh, I., 2012. Ovaprim doses effects on eggs of 
African mudfish Clarias gariepinus. Int. J. Life Sci. Pharma Res., 2(2), p.6-9.

Akombo, P.M., Atile, J.I. and Obaje, J.A., 2018. The effects of some physicochemical parameters on the creeding of catfish (Clarias gariepinus) using ovaprim and ovatide. Int. J. Innov. Studies Aquat. Biol. Fish., 4(3), p.19.

Aryani, N., Suharma, I. and Syandri, H., 2018. Reproductive performance of Asian catfish (Hemibagrus wyckii Bleeker, 1858), a candidate species for aquaculture. F1000Research, 7, p.683.

Cejko, B.I., Krejszeff, S., Zarski, D., Judycka, S., Targonska, K. and Kucharczyk, D., 2018. Effect of carp pituitary homogenate $(\mathrm{CPH})$ and sGnRHa (ovaprim) on nothern pike (Esox lucius) spermiation stimulation and its effect on quantity and quality of sperm. Animal Reprod. Sci., 193, p.217-225.

Charan, R., Dube, K., Babu, P.P.S., Roy, S.D., Sharma, R.,Rao, P.S., Prasad, J.K. and Angel, J.R.J., 2016. Comparison of reproductive performance of Clarias batrachus (Linnaeus, 1758) collected from three Indian rivers. Indian J. Fish., 63(3), p.57-62.

Chaube, R., Singh, R.K. and Joy, K.P., 2014. Effects of ovaprim, a commercial spawning inducer, on vasotocin and steroid hormone profiles in the catfish Heteropneustes fossilis: in vivo and in vitro studies. Gen. Comp. Endocrinol., 195, p.190200.

de Graaf, G. and Janssen, H., 1996. Artificial reproduction and pond rearing of the African catfish Clarias gariepinus in Sub-Saharan Africa-A Handbook. FAO Fisheries Technical Paper. No. 362. FAO, Rome. 73 p.

Drori, S., Ofir, M., Levavi-Sivan, B. and Yaron, Z., 1994. Spawning induction in common carp Cyprinus carpiousing pituitary extract or $\mathrm{GnRH}$ superactive analogue combined with metoclopramide: analysis of hormone profile, progress oocyte maturation and independence on temperature. Aquaculture, 119, p.393-407.

Hafeez-ur-Rehman, M., Ashraf, M., Abbas, F., Iqbal, K.J., Qureshi, I.A. and Andleeb, S., 2015. Effect of different synthetic hormones and/or their analogues on induced spawning in Channa marulius. Pakistan J. Zool., 47(3), p.745-752.

Hassan, A., Ambak, M.A. and Samad, A.P., 2011. Crossbreeding of Pangasianodon hypophthalmus (Sauvage, 1878) and Pangasius nasutus (Bleeker, 1863) and their larval development. J. Sustain. Sci. Manag., 6(1), p.28-35.

IDRC., 1998. Fish spawning kit. International Development Research Centre, Ottawa, Canada. 4 p.

Kahkesh, F.B., Feshalami, M.Y., Amiri, F. and Nickpey, M., 2010. Effect of ovaprim, ovatide, HCG, LHRH-A2, LHRHA2+CPE, and carp pituitary in benni (Barbus sharpeyi) artificial breeding. Glob. Vet., 5(4), p.209-214.

Khan, M.F., Ali, M.R., Afzal, M., Rab, A., Awan, M.A. and Ahmad, A., 2014. Induced breeding of giant catfish, Sperata seenghala using hormonal analogues. Int. J. Vet. Sci., 3(3), p.125-128.

Marimuthu, K., Satthiyasilan, N., Rahman, M.A., Arshad, A., Raj, M.G. and Arockiaraj, J., 2015. Induced ovulation and spawning of African catfish Clarias gariepinus (Bloch) using ovaprim. J. Environ. Biotechnol. Res., 1(1), p.2-9.

Mittlemark, J. and Kapuscinki, A., 2000. Induced reproduction in fish. Minnesota Sea Grant. University of Minnesota, USA. 12 p.

Muchlisin, Z.A., Arfandi, G., Adlim, M., Fadli, N. and Sugianto, S., 2014. Induced spawning of seurukan fish, 
Osteochilus vittatus (Pisces: Cyprinidae) using ovaprim, oxytocin and chicken pituitary gland extracts. AACL Bioflux, 7(5), p.412-418.

Mukti, A.T., 2002. Teknologi perbenihan dalam rangka peningkatan kualitas dan produksi ikan. Pelatihan dan Gelar Rekayasa Teknologi Pembenihan Ikan di Unit Pembenihan Ikan Sentral Anjungan Kalimantan Barat, 31 Oktober-1 Nopember 2002. p.20.

Mukti, A.T., Arief, M. and Satyantini, W.H., 2010. IbM Pondok Pesantren Manba'ul Adhim, Desa Bagbogo, Kecamatan Tanjung Anom, Kabupaten Nganjuk, Jawa Timur. Iptek bagi Masyarakat (IbM) DP2M, Dirjen Dikti, Kemdiknas. 20 hal.

Mukti, A.T. and Rustidja, 2002. Teknologi perbenihan. Pelatihan Teknologi Kelautan Angkatan I Diklat Propinsi Jawa Timur. Surabaya, 24 Juni-5 Juli 2002. 26 hal.

Nandeesha, M.C., Das, S.K., Nathaniel, D.E. and Varghese, T.J., 1990. Breeding of carps with ovaprim in India. Spec. Publ. Asian Fish. Soc.Indian Branch, Mangalore, India. No. 4.41 p.

Odedeyi, D.O., Gbore, F.A. and Ademoye, O., 2014. Influence of the length of time after hormonal stimulation on the milt quality of African catfish Clarias gariepinus brood stock. Aust. J. Basic \& Appl. Sci., 8(1), p.407-412.

Pao, X.,Kuanhong, M., Jian, Z., Jianxin, W. and Yongseng, G., 1999. Comparative studies on spawninginducing using ovaprim and other hormone. Freshwater Fisheries Research Center, Chinese Academy of Fishery Science, Wuxi, China. 12 p.

Satyantini, W.H., Mukti, A.T., Arief, M. and Sahidu, A.M., 2009. Pengembangan hatchery dan budidaya ikan lele dumbo Clarias gariepinus melalui program induced spawning guna pemberdayaan ekonomi masyarakat desa di daerah rawan pangan dan kemiskinan Kabupaten Pacitan, Jawa Timur. Ipteks di Daerah Rawan Pangan dan Kemiskinan, DP2M, Dikti, Depdiknas. p.30.

Shoaib, M., Nasir, M. and Kareem, A., 2014. Effects of ovaprim on reproductive performance of fresh water carp, Cirrhina mrigala (F. Hamilton, 1822). Int. J. Biol. Res., 2(2), p.129-134.

Singh, A.A., Nanda, S., Moharana, N.K. and Priyadarsini, S., 2015. Comparative study on the effect of ovaprim and Wova-FH oninduced breeding response on Anabas testudineus (Bloch). Asian J. Animal Sci., 10(1), p.64-68.

Usman, I., Auta, J. and Abdullahi, S.A., 2015. Effect of monthly variation in water temperature onartificial breeding of common carp (Cyprinus carpio L.) in Zaria, Nigeria. Int. $J$. Fish. Aquat. Studies, 3(2), p.353-356. Wahyudi, 1995. Penggunaan ekstraks hipofisis sapi dan PMSG-hCG sebagai bahan untuk menghasilkan sperma dan daya fertilisasi telur ikan nila merah Oreochromis niloticus. Thesis. Pascasarjana Universitas Airlangga. Surabaya. p.71.

Zadmajid, V., 2016. Comparative effects of human chorionic gonadotropin (hCG) and Ovaprim ${ }^{\mathrm{TM}}$ (sGnRHa + domperidone) on the reproductivecharacteristics of wildcaught male Longspine scraper, Capoeta trutta (Heckel, 1843). Aquaculture, 463, p.7-15.

Zadmajid, V., Bashiri, S., Sharafi, N. and Butts, I.A.E., 2018. Effect of hCG and Ovaprim $^{\mathrm{TM}}$ on reproductive characteristic of male Levantine scraper, Capoeta damascina (Valenciennes, 1842). Theriogenology, 115, p.45-56.

Zadmajid, V., Mirzaee, R., Hoseinpour, H., Vahedi, N. and Butts, I.A.E., 2017. Hormonal induction of ovulation 
Journal of Aquaculture and Fish Health Vol. 8 No.1

using $\quad$ Ovaprim $^{\mathrm{TM}} \quad$ [(D-

Arg6,Pro9Net)-sGnRH +

domperidone] and its impact on embryonic development of wildcught Longspine scraper, Capoeta trutta (Heckel, 1843). Animal Reprod. Sci., 187, p.79-90. 